\title{
Development of a Prototype for the Treatment of Water Contaminated With Glyphosate
}

\author{
Julio Cesar Maciel Santos' \\ Andressa Jenifer Rubio" \\ Jean Carlos Araujo de Sousal'I \\ Ana Carolynna S. AlmeidalV \\ Rosângela Bergamasco ${ }^{\mathrm{V}}$ \\ Natália Ueda Yamaguchi ${ }^{\mathrm{VI}}$
}

\begin{abstract}
One of the current challenges is to meet the demands for quality water since the contamination of bodies of water has been intensified in the last years with the increase in the use of pesticides. Therefore, finding a way to remove contamination by pesticides from water becomes a relevant work. In this study, it was presented the design and construction of a pilot-scale batch reactor prototype in order to remove the herbicide glyphosate from artificially contaminated water using a graphene hybrid composite with manganese ferrite, $\mathrm{MnFe2O4-G}$, as an adsorbent. For the reactor design, it was initially required to know the steps necessary for the removal of the glyphosate from water, according to the chosen hybrid compound for the removal. After the steps were determinated, the components were selected to compose the treatment system. The layout of the prototype was defined and the positions of the elements and materials were chosen. Finally, the prototype was built and tested in the laboratory. The results showed that within 15 minutes the separation was completed and $70 \%$ of the adsorbent was recovered in the magnetic separator after 4 complete cycles of treatment. It was concluded that the prototype built fulfills the objective for which it was proposed, presenting the advantage of having all the steps of adsorption and desorption for glyphosate decontamination in the same equipment, being able to be expanded for use in effluent treatment plants.
\end{abstract}

Keywords: Magnetic separation; Graphene; Adsorption

\footnotetext{
' Master Student, Master's Program in Clean Technologies, Unicesumar, Maringá, PR, Brasil - julio503@hotmail.com

"Master Student, Master's Program in Clean Technologies, Unicesumar, Maringá, PR, Brasil andressajrubio@gmail.com

III Master Student, Master's Program in Clean Technologies, Unicesumar, Maringá, PR, Brasil jeancarloseletrica@gmail.com

IVEnvironmental Engineering Student, Environmental Engineering, Unicesumar, Maringá, PR, Brasil carol.severo10@gmail.com

Professor, Chemical Engineer Department, State University of Maringá, Maringá, PR, Brasil ro.bergamasco@hotmail.com

VIProfessor, Master's Program in Clean Technologies, ICETI, Unicesumar, Maringá, PR, Brasil nataliaueda@hotmail.com
} 


\section{Introduction}

Meeting the demand for good quality water for cities is one of the major current challenges. Population growth, food production and industrial development can lead to serious problems in water supply both in increasing demand for consumption and in contamination of bodies of water. Agriculture consumes around $70 \%$ of the world's water resources, followed by the industrial sector with $20 \%$ and the domestic sector with 10\%. These values may vary according to the country's development (UNESCO, 2014).

Ensuring the availability and sustainable management of water and sanitation for all is one of the 17 sustainable development goals adopted in the General Resolution of the United Nations in September 2015. This resolution known as Agenda 2030 in its objective 6, subitem 6.3, mentions improving water quality, reducing pollution, eliminating eviction and minimizing the release of hazardous chemicals and materials (United Nations, 2015).

The use of agrochemicals in agriculture has been intensified in recent decades with the aim of increasing food production; on the other hand, these pesticides can be sources of contamination for rivers and groundwater and, because of their intrinsic nature, it can cause damages to human health that vary according to the active principle and the absorbed dose (BRASIL, 2016).

Among the pesticides, glyphosate is the most sold in the world. In Brazil alone, glyphosate represents $40 \%$ of sales of pesticides. Glyphosate is an organophosphorus, non-selective, systemic and post-emergent herbicide used in many food and non-food crops, as well as non-agricultural areas, such as recreational areas (WEIDENHAMER and CALLAWAY, 2010). Its physicochemical properties are relatively low molecular weight, high polarity, high water solubility, low solubility in organic solvents, amphoteric behavior, and easy formation of metal complexes (SANCHIS et al., 2012).

In its early years, it was believed that this herbicide, did not cause damage to human health but with the intensification of its application in crops due to the 
development of seeds resistant to this herbicide, new studies have pointed out the contrary (CARNEIRO et al., 2015). One study showed that initial toxicity tests indicated that glyphosate had low toxicity risks, prompting regulatory authorities around the world to allow for high levels of exposure to glyphosate; however, studies published in the last decade point to the need for a new look at the toxicity of glyphosate. In addition, the authors state that the International Agency for Research on Cancer, linked to the World Health Organization, has recently concluded that glyphosate is "probably carcinogenic to humans" (MYERS et al., 2016; TARONE, 2018).

Other studies also claim that glyphosate poses risks to human or other mammalian health such as: acute and chronic neurotoxicity in rats(CATTANI et al., 2014), neurodegenerative diseases such as Parkinson's disease (GUI et al., 2012) and endocrine problems in rats (CLAIR et al., 2012).

The persistence and transport of glyphosate in the soil are dependent on soil composition, climatic conditions and microbiological activity, as well as agricultural management (GIMSING et al., 2004). Most of the literature reports biological impacts of glyphosate based on laboratory tests or short-term field studies (HELANDER et al., 2012).

In addition, due to the wide variety of application methods and climatic conditions, a significant amount of glyphosate reaches the soil and may be leached from the root region in drainage water and groundwater. Experimental observations combined with transport studies suggest that the transport of glyphosate may occur due to heavy rains shortly after application in moist soils leading to the formation of preferential pathways flows (DAMONTE et al., 2007).

In this context, one of the promising technologies for the removal of pollutants from water is adsorption since it is a low cost and high efficiency method. Carbonbased materials, such as graphene, have been extensively studied in adsorption applications to remove contaminants from water due to their properties (CHOWDHURY et al., 2014). One of the difficulties in the use of adsorbent materials is its removal after the adsorption process. The association of graphene with magnetic materials may facilitate such removal work because the adsorbent material may be 
retained by a magnetic field without the need for filtration or centrifugation (WANG et al., 2015).

In comparison with other materials formed by carbon, graphene has attracted the attention of researchers due to its properties of an efficient association with metals and metal oxides forming hybrids; this is owing to its properties of high electrical conductivity, mechanical resistance and large specific area. Yao et al. (2014) used a $\mathrm{MnFe}_{2} \mathrm{O}_{4}$ graphene hybrid as catalysts in the removal of organic pollutants from water. Kumar et al. (2014) also used a graphene oxide hybrid $\left(\mathrm{MnFe}_{2} \mathrm{O}_{4}\right)$ in the removal of lead and arsenic from contaminated water. The authors considered that the easy magnetic separation, high removal efficiency, large surface area and the fact of being reusable are factors that make this hybrid a strong candidate to be used as a low cost adsorbent in the removal of toxic metals from water.

Specifically for the removal of glyphosate from water, in a previous work it was synthesized, characterized and tested the $\mathrm{MnFe}_{2} \mathrm{O}_{4}-\mathrm{G}$ composite succeeding in removing this contaminant from water (YAMAGUCHI et al., 2016). Although there are several recent studies using magnetic graphene for water treatment, it was noticed that an industrial application was not aimed, and it was used batch scale laboratorial assays with different equipment for each step of the processes.

This whole scenario motivated a previous research for the development of a prototype in a pilot scale using the $\mathrm{MnFe}_{2} \mathrm{O}_{4}-\mathrm{G}$ composite. The results were satisfactory, the prototype was evaluated in relation to the removal of glyphosate in four complete cycles of adsorption and desorption, obtaining a $84.5 \%$ removal of glyphosate in the first cycle, $80 \%$ in the second and third cycle and $60 \%$ in the fourth cycle (SANTOS et al., 2017).

Therefore, the proposal addressed in the present research had as objective the design and construction of a single prototype that gather all the steps of water decontamination with glyphosate using a hybrid compound of $\mathrm{MnFe}_{2} \mathrm{O}_{4}-\mathrm{G}$, aiming to provide a concept for applications in water treatment plants. Thus, it was focused the determination of the steps to glyphosate removal, the definition of the layout, the 
selection of materials, the project elaboration, the construction of the prototype in a reduced scale.

\section{Materials and methods}

\subsection{Determination of the steps for the removal of glyphosate using hybrid manganese} ferrite compound and graphene

Initially, the volume of $1 \mathrm{dm}^{3}$ of water was assigned to be treated. After that, it was necessary to determine the steps for the treatment of water contaminated with glyphosate, in order to design the prototype. For that, it was used the work developed by Yamaguchi et al. (2016) and Santos et al. (2017) for the determination of these steps and analysis methods.

The first step of the process was to place $1.0 \mathrm{~g}$ of particles in contact with glyphosate contaminated water (20 ppm) and stirred them for a period of 5 hours in order to perform the adsorption. In this way, the first part of the prototype worked with a tank coupled with a stirrer. This step was called the adsorption step.

After the adsorption step, the particles had to pass through a magnetic field to be separated from the water that was decontaminated. A magnetic separator connected in parallel with the adsorption reactor was designed as shown in Figure 1. In that separator, a magnetic field was approached or moved away from the walls of the reservoir according to the need for separation. The flow velocity was reduced and the water was pumped from the adsorption reactor to the magnetic separator and returned to the adsorption tank. As a result, the water passed several times through the magnetic field for a better retention of the particles. In order to measure the efficiency of the magnetic separator, the $\mathrm{MnFe}_{2} \mathrm{O}_{4}-\mathrm{G}$ particles were weighed at the beginning of the experiment and at the end of all 4 cycles. This step was called magnetic separation. 
Figure 1 - Flow diagram of the adsorption reactor and magnetic separator

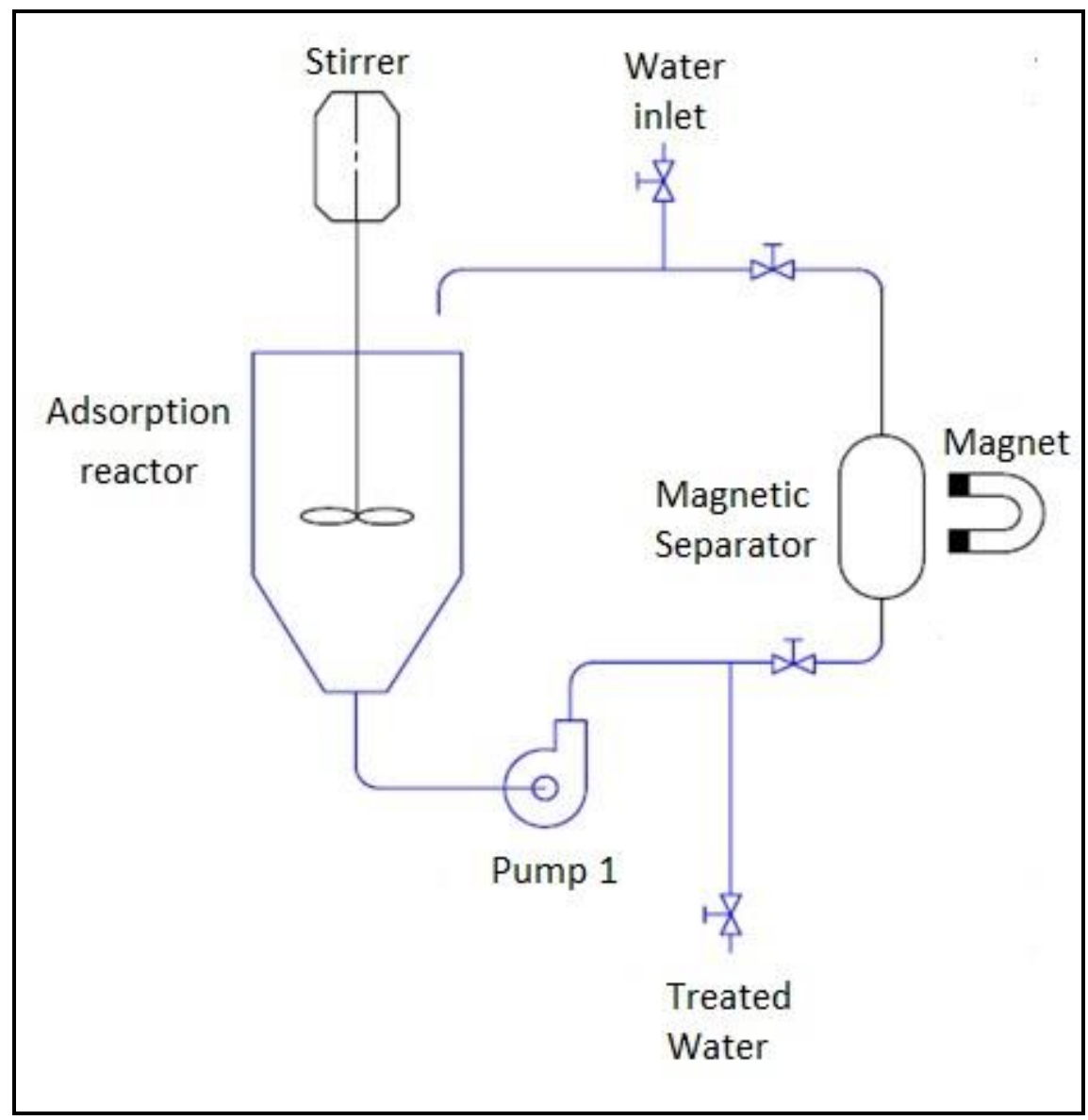

After the magnetic separation, the decontaminated water was drained and discarded. In an industrial-scale situation, this water could be referred to other treatments according to the necessity.

After this first magnetic separation, the particles contaminated by glyphosate were retained in the separator and must undergo a desorption process so that the contaminant is removed from the particles, allowing them to be reused in new cycles of adsorption. In the desorption process, the particles were contacted with a solution of $0.1 \mathrm{M} \mathrm{NaOH}$ and stirred for a period of time empirically defined in 15 minutes. For this purpose, the same magnetic separator reservoir was used, this time without the magnetic field, and a pump was used as a stirrer, as shown in Figure 2. The desorption was completed and the particles were again magnetically 
Figure 2 - Flow diagram of the desorption system

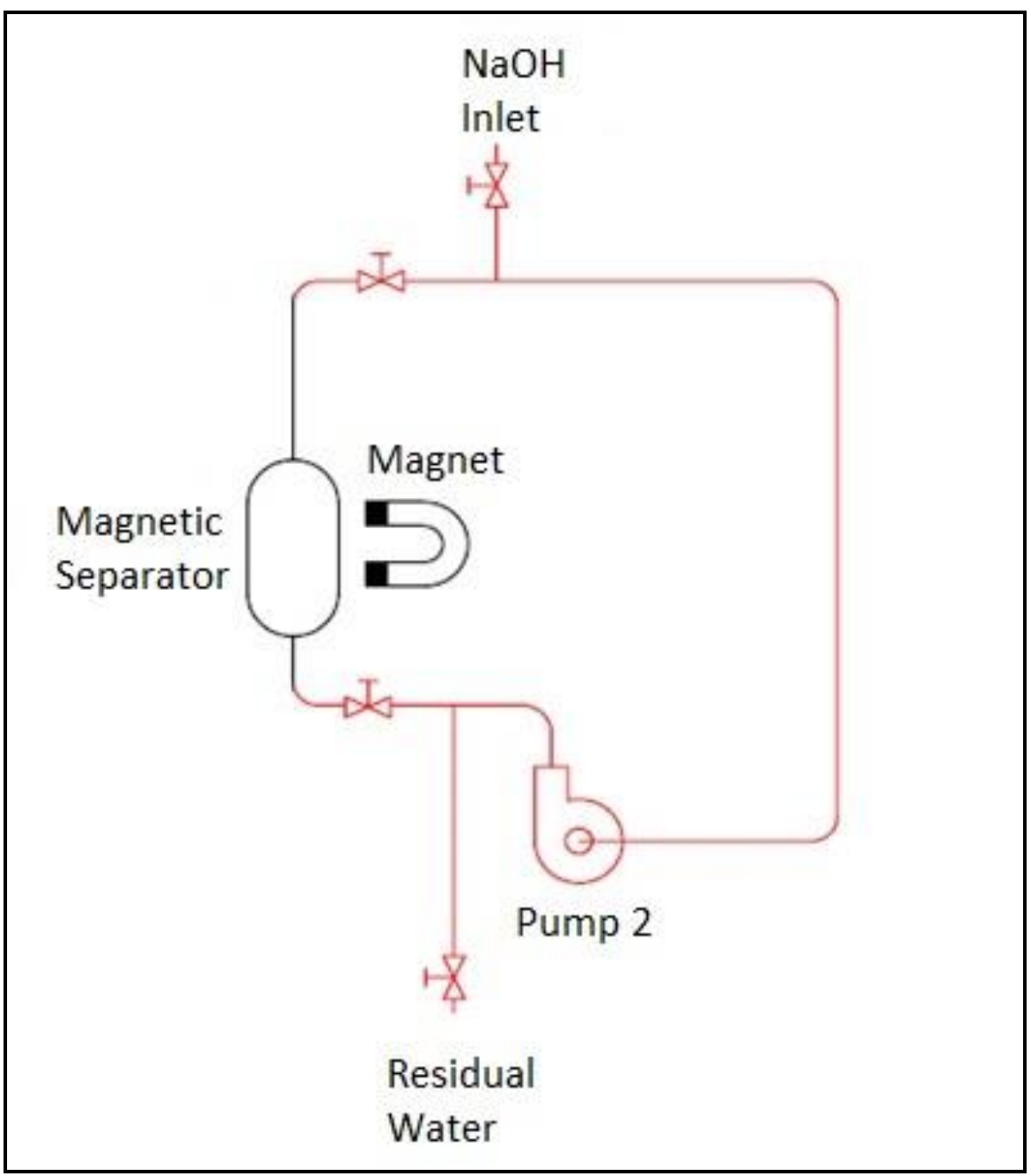

After desorption, these particles were rinsed with pure or distilled water to remove the excess of $\mathrm{NaOH}$ to which the particle had been exposed. This rinsing was performed in the same manner as in the desorption using the magnetic separator resevoir without the field and a 10 minute empirically assigned time bomb.

The rinsing step may be performed more than once to ensure maximum removal of $\mathrm{NaOH}$. After each rinsing step, a new magnetic separation was performed, the rinse water was discarded, and the $\mathrm{MnFe}_{2} \mathrm{O}_{4}-\mathrm{G}$ particles were ready for further treatment processes. This stage was called rinsing.

All steps were cited and were performed in a predetermined order, according to the flowchart shown in Figure 3. 
Figure 3 - Flowchart with all treatment steps

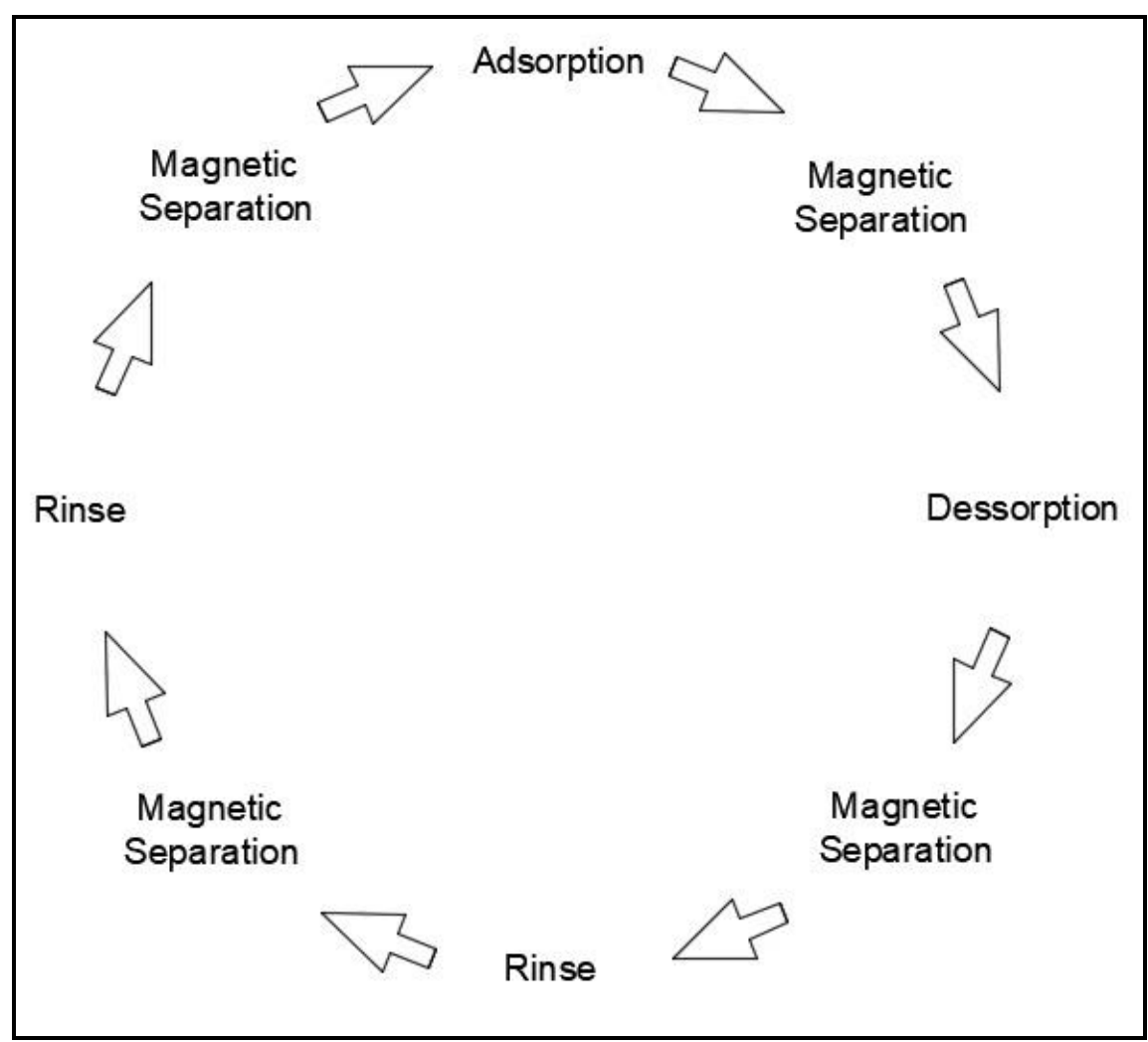

\subsection{Definition of materials}

The first components to be acquired were the pumps. For this, since the prototype should treat the volume of $1 \mathrm{dm}^{3}$ of water, it was attributed that the pump to be selected should have a flow rate of around $5 \mathrm{dm}^{3} \mathrm{~min}^{-1}$. For a better control of the flow, the pump should be fed by direct current of electricity; therefore, by varying the voltage of the pump, it would be possible to vary the flow rate.

The adsorption reactors and magnetic separator were made from PET bottles, with a volume of $1.5 \mathrm{dm}^{3}$ for the adsorption reactor and $0.1 \mathrm{dm}^{3}$ for the magnetic separator. The hoses used were of silicone, $10 \mathrm{~mm}$ and transparent.

The magnets selected for the magnetic separator were neodymium, type N52, with dimensions of $40 \times 20 \times 10 \mathrm{~mm}$.

To facilitate the assembly, $10 \mathrm{~mm}$ pneumatic connections have been chosen so that the hoses could be fastened and de-attached quickly like a quick coupling. Mass and epoxy resin were used to fix the connections in the reservoirs. 


\section{Results and discussion}

\subsection{Prototype design}

Figure 4 shows the layout defined for the construction of the prototype. Note that the two systems that make up the removal process are present and interconnected. On the left side of the layout is the glyphosate adsorption system and on the right side, the particle regeneration system (desorption). This was the initial proposition for setting up the prototype. Nonetheless, the adsorption and desorption processes were not constructed interconnected in this first moment. They were constructed separately but the interconnection can be easily accomplished by means of valves as shown in Figure 4 .

Figure 4 - Prototype and its components: 1 stirrer; 2 adsorption reactor; 3 and 4 pumps; 5, 6, 7 and 8 valves; 9 magnetic separator

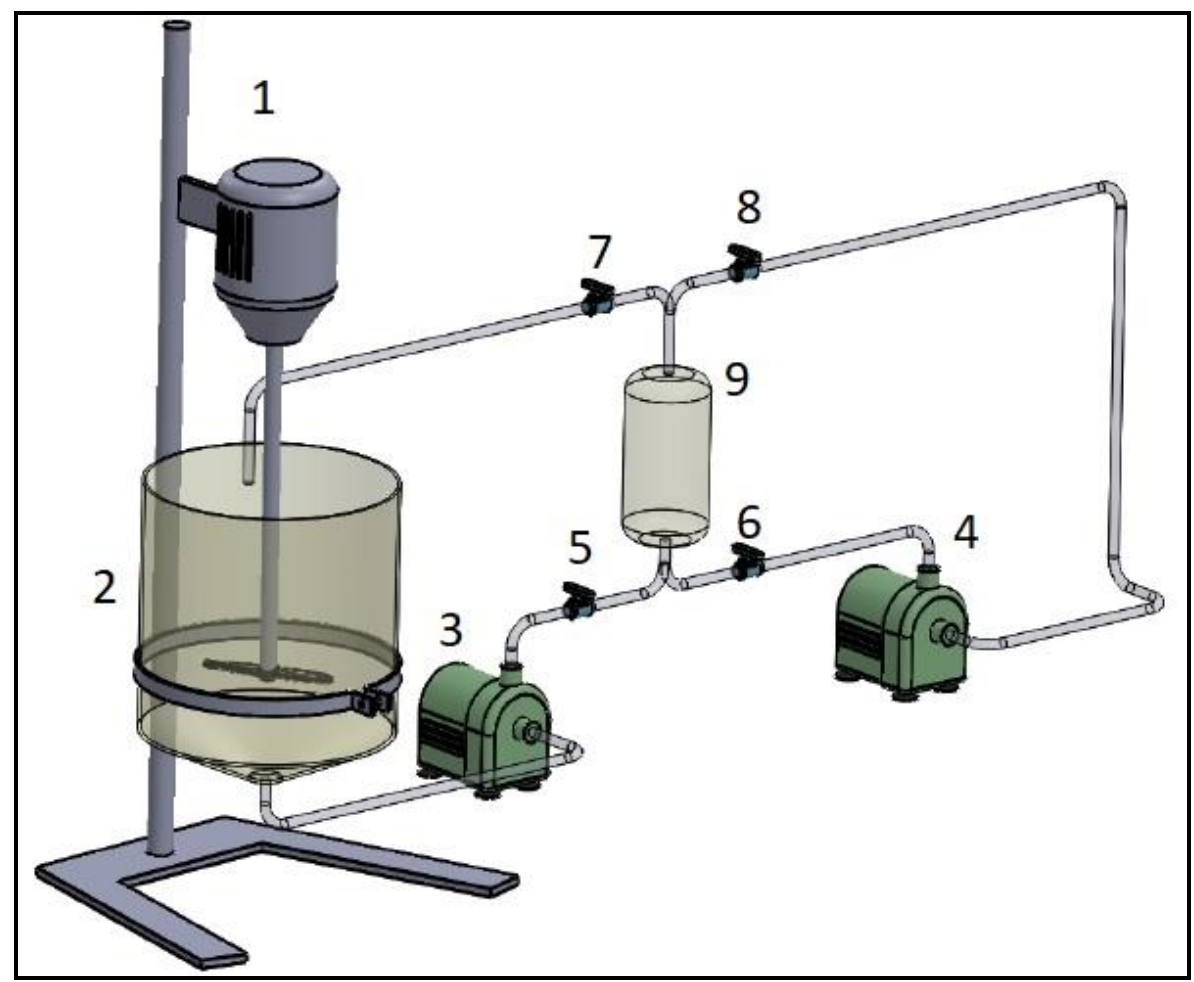

\subsection{Construction of the prototype}

In Figures 5 and 6, it is possible to observe the constructed prototype and being tested in the laboratory. Figure 5 shows the layout with the configuration projected 
next to the built prototype, showing the adsorption step. It also shows that the propeller stirrer was not required inside the adsorption reactor, due to the fact that the selected and installed pump performed the agitation of the particles successfully. Another modification concerns the entry of water into the system, which in the initial layout should be performed by a pipe. The water inflow into the system was carried out directly over the upper inlet of the reactor, by manually supplying $1 \mathrm{dm}^{3}$ of artificially contaminated water with $20 \mathrm{ppm}$ of glyphosate.

Figure 5 - Original layout alongside the built prototype with the steps of adsorption and magnetic separation

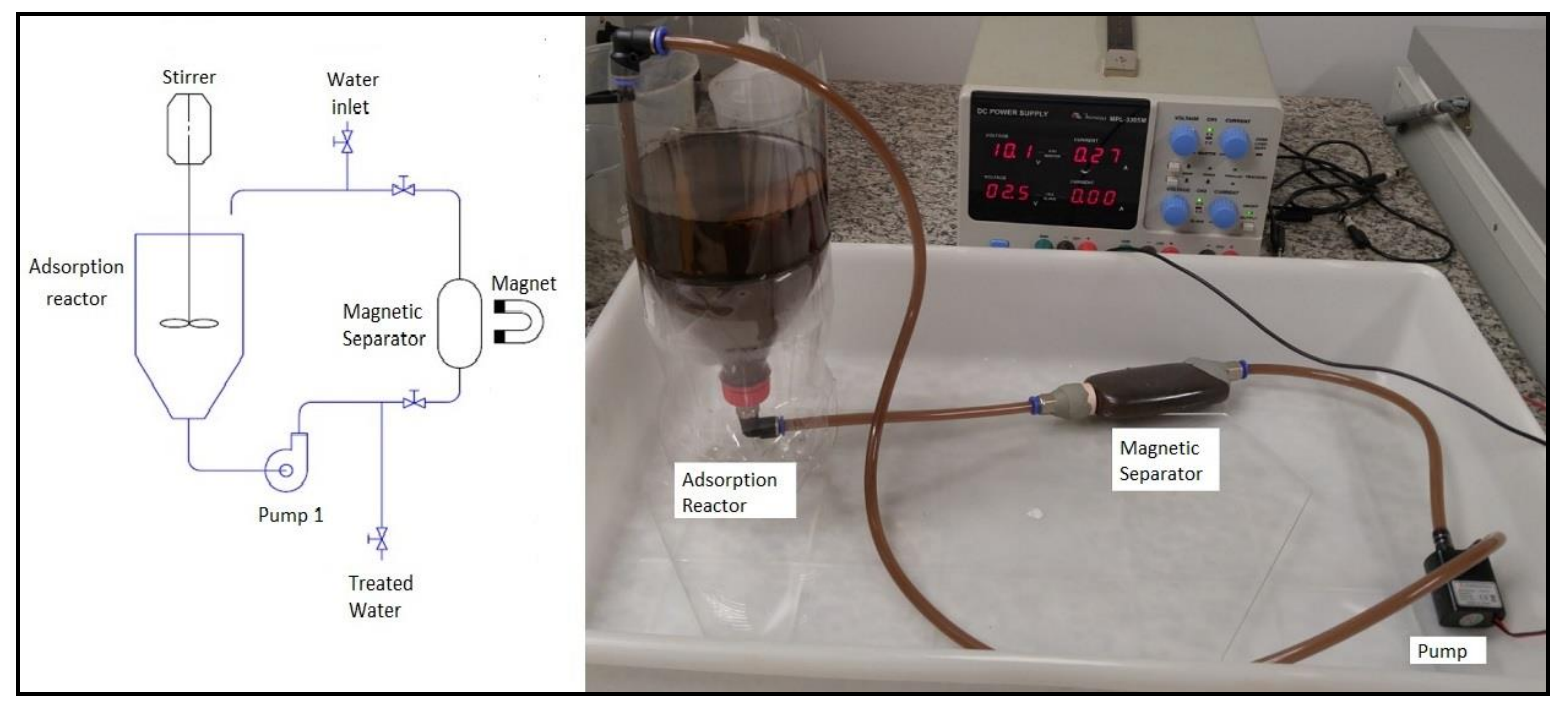

It is further noted that the output of the treated water, which in the original layout would be between the pump and the magnetic separator by means of piping, occurred just before the magnetic separator by simply disconnecting the hose before entering the separator. It is suggested, for later studies, that all components of the original layout are connected, except the agitator which proved to be unnecessary, just to make the system configure itself with a better presentation. In terms of removal efficiency, it should be noted that the simplifications adopted did not compromise the results.

Figure 6 shows the layout with the configuration designed next to the built prototype, showing the desorption stage of the particles. As previously explained, 
the entry of $\mathrm{NaOH}$ into the system and the exit of the waste water, which in the initial layout should be performed by a suitable piping, occurred just before the magnetic separator by simply disconnecting the hose.

Figure 6 - Original layout next to the prototype built with the adsorption and magnetic separation steps

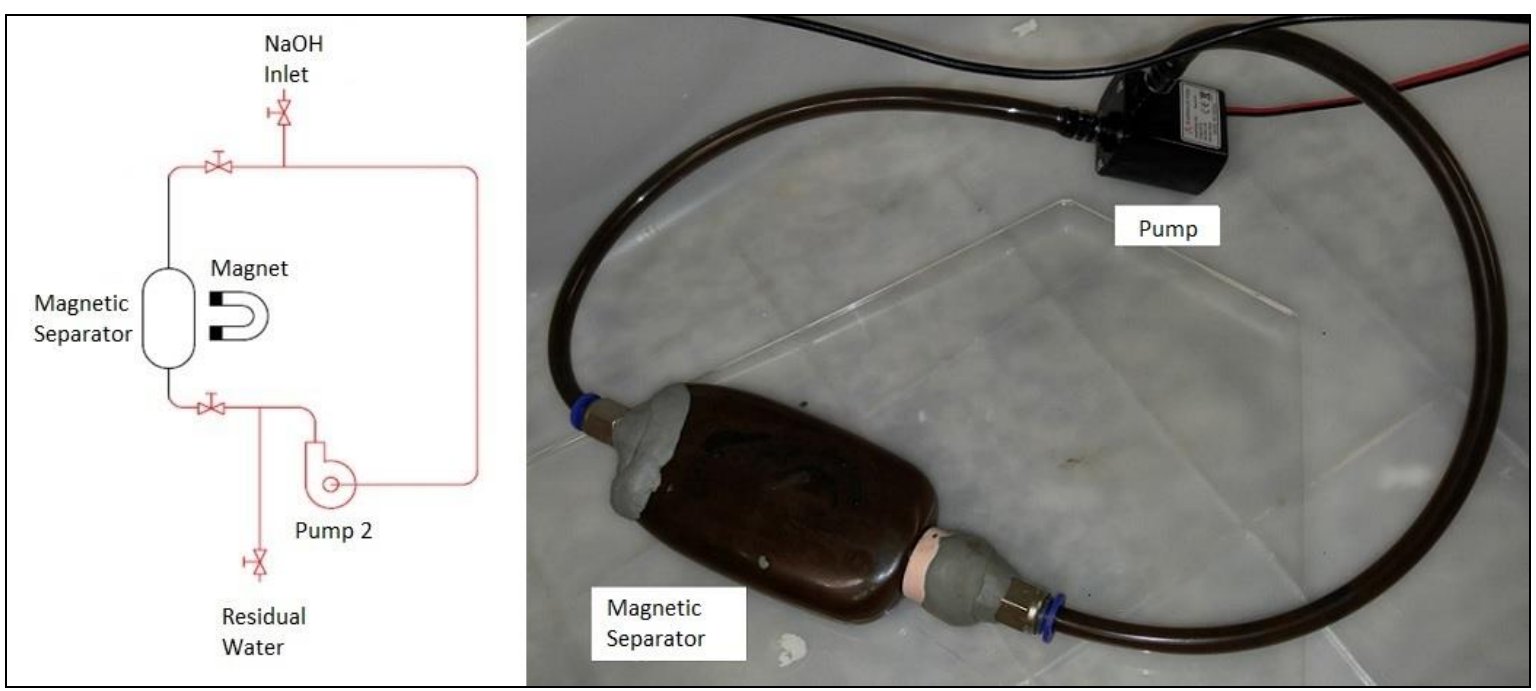

After the construction of the prototype, some tests of its operation were carried out in order to identify possible leaks and other problems not foreseen in the project.

\subsection{Prototype test}

A test was performed to verify the prototype's functioning and correction of possible problems such as leaks. Regarding the magnetic separation, it was found empirically that within 15 minutes the separation was completed and $70 \%$ of the particles were recovered after 4 complete cycles of treatment, while 30\% of the particles were lost in the treated water in the regeneration $\mathrm{NaOH}$ solutions, in the waters of rinsing and part were deposited in the walls of the tanks and pipes.

The feasibility of use and regeneration of the material in the prototype was also evaluated in an earlier study (SANTOS et al., 2017). The results showed that the treatment is promising, since there was significant water decontamination in four 
complete cycles, with $84.5 \%$ of glyphosate removal in the first cycle, $80 \%$ in the second and third cycle and $60 \%$ in the fourth cycle.

A previous work (YAMAGUCHI et al., 2016) has also studied the magnetic graphene composite, $\mathrm{MnFe}_{2} \mathrm{O}_{4}-\mathrm{G}$. The material was was characterized using various techniques, and then applied to remove glyphosate from water in batch scale experiments. The results showed that the hybrid composite presented a BET area of $305.5 \mathrm{~m}^{2} / \mathrm{g}$ and was well dispersed on graphene nanosheets. It was also proposed that the adsorption mechanism of glyphosate on $\mathrm{MnFe}_{2} \mathrm{O}_{4}-\mathrm{G}$ was through a combination of an electrostatic interaction with an ion exchange that was favoured at low temperature. The maximum adsorption capacity of glyphosate adsorption was $39 \mathrm{mg} \mathrm{g}^{-1}$ at $5^{\circ} \mathrm{C}$. The kinetics and isotherm data obtained fitted well with pseudo-second-order kinetics and the Freundlich isotherm model, indicating a multilayer chemisorption in a heterogeneous surface. It was also determined that the adsorption of glyphosate on the $\mathrm{MnFe}_{2} \mathrm{O}_{4}-\mathrm{G}$ was spontaneous and exothermic.

There are few studies of glyphosate removal from aquous solutions in the literature. Some works studied the adsorption of glyphosate herbicide on activated carbon and biochar. Mohsen et al. (2010) obtained a maximum adsorption capacity of $48.4 \mathrm{mg} \mathrm{g}^{-1}$ in activated carbon derived from a newspaper industry waste. Mayakaduwa et al. (2015) determined the kinetic and equilibrium mechanisms for the adsorption of glyphosate by biochar and obtained a maximum adsorption capacity of $44 \mathrm{mg} \mathrm{g}^{-1}$. Both results were slightly higher when compared with the maximium adsorption capacity of $\mathrm{MnFe}_{2} \mathrm{O}_{4}-\mathrm{G}$ (39 $\mathrm{mg} \mathrm{g}^{-1}$ ) (YAMAGUCHI et al., 2016). However, the advantage of $\mathrm{MnFe}_{2} \mathrm{O}_{4}-\mathrm{G}$ is its application in a prototype presenting all the steps of adsorption and desorption for glyphosate decontamination in the same equipment using its capability of reusability and magnetic separation.

\section{Conclusion}

The prototype was conceived and designed with its components, materials and layout defined. After constructing the prototype, it was possible to achieve the goal of 
bringing all the treatment steps together into a single device, although at the moment it has been built in two parts separately, which can be solved with the use of valves. The tests were performed according to what was proposed and no operational problems were identified. Although the recovery of the particles in the magnetic separator has been satisfactory, improvements in this separation can be developed in other studies. Additional tests may be performed for future work for better understanding of the process, such as $\mathrm{pH}$, replicates, optimization of stirring speed, adsorption and desorption times, costs of the processes, reusability of the adsorbent, use of different contaminants and the use of real wastewaters. Also full-scale studies are recommended in order to apply the concepts in a water treatment plant.

\section{References}

BRASIL. Relatório Nacional de Vigilância em Saúde de Populações Expostas a Agrotóxicos. Brasilia: Ministério da Saúde, p.141, 2016

CARNEIRO, F. F.; AUGUSTO, L. G. D. S.; RIGOTTO, R. M.; FRIEDRICH, K.; BÚRIGO, A. C. Um alerta sobre os impactos dos agrotóxicos na saúde. Rio de Janeiro/São Paulo: EPSJV Editora Expressão Popular 2015.

CATTANI, D.; CAVALLI, V.; RIEG, C. E. H.; DOMINGUES, J. T.; DAL-CIM, T.; TASCA, C. I.; SILVA, F.; ZAMONER, A. Mechanisms underlying the neurotoxicity induced by glyphosate-based herbicide in immature rat hippocampus: Involvement of glutamate excitotoxicity. Toxicology, v. 320, n., p. 34-45, 2014.

CHOWDHURY, S.; BALASUBRAMANIAN, R. Recent advances in the use of graphenefamily nanoadsorbents for removal of toxic pollutants from wastewater. Advances in Colloid and Interface Science, v. 204, n. Supplement C, p. 35-56, 2014.

CLAIR, É.; MESNAGE, R.; TRAVERT, C.; SÉRALINI, G.É. A glyphosate-based herbicide induces necrosis and apoptosis in mature rat testicular cells in vitro, and testosterone decrease at lower levels. Toxicology in Vitro, v. 26, n. 2, p. 269-279, 2012.

DAMONTE, M.; TORRES SÁNCHEZ, R. M.; DOS SANTOS AFONSO, M. Some aspects of the glyphosate adsorption on montmorillonite and its calcined form. Applied Clay Science, v. 36, n. 1-3, p. 86-94, 2007. 
GIMSING, A. L.; BORGGAARD, O. K.; BANG, M. Influence of soil composition on adsorption of glyphosate and phosphate by contrasting Danish surface soils. European Journal of Soil Science, v. 55, n. 1, p. 183-191, 2004.

GUI, Y.-X.; FAN, X.-N.; WANG, H.-M.; WANG, G.; CHEN, S.-D. Glyphosate induced cell death through apoptotic and autophagic mechanisms. Neurotoxicology and Teratology, v. 34, n. 3, p. 344-349, 2012.

HELANDER, M.; SALONIEMI, I.; SAIKKONEN, K. Glyphosate in northern ecosystems. Trends in Plant Science, v. 17, n. 10, p. 569-574, 2012.

KUMAR, S.; NAIR, R. R.; PILLAI, P. B.; GUPTA, S. N.; IYENGAR, M. A. R.; SOOD, A. K. Graphene Oxide-MnFe2O4 Magnetic Nanohybrids for Efficient Removal of Lead and Arsenic from Water. ACS Applied Materials \& Interfaces, v. 6, n. 20, p. 17426-17436, 2014.

MAYAKADUWA, S. S.; KUMARATHILAKA, P.; HERATH, I.; AHMAD, M.; AL-WABEL, M.; OK, Y. S.; USMAN, A.; ABDULJABBAR, A.; VITHANAGE, M. Equilibrium and kinetic mechanisms of woody biochar on aqueous glyphosate removal. Chemosphere, v., n., p., 2015.

MOHSEN NOUROUZI, M.; CHUAH, T. G.; CHOONG, T. S. Y. Adsorption of glyphosate onto activated carbon derived from waste newspaper. Desalination and Water Treatment, v. 24, n. 1-3, p. 321-326, 2010.

MYERS, J. P.; ANTONIOU, M. N.; BLUMBERG, B.; CARROLL, L.; COLBORN, T.; EVERETT, L. G.; HANSEN, M.; LANDRIGAN, P. J.; LANPHEAR, B. P.; MESNAGE, R.; VANDENBERG, L. N.; VOM SAAL, F. S.; WELSHONS, W. V.; BENBROOK, C. M. Concerns over use of glyphosate-based herbicides and risks associated with exposures: a consensus statement. Environmental Health, v. 15, n., p. 13, 2016.

SANCHIS, J.; KANTIANI, L.; LLORCA, M.; RUBIO, F.; GINEBREDA, A.; FRAILE, J.; GARRIDO, T.; FARRE, M. Determination of glyphosate in groundwater samples using an ultrasensitive immunoassay and confirmation by on-line solid-phase extraction followed by liquid chromatography coupled to tandem mass spectrometry. Anal Bioanal Chem, v. 402, n. 7, p. 2335-2345, 2012.

SANTOS, J. C. M.; SOUSA, J. C. A.; ALMEIDA, A. C. S.; HOMEM, N. C.; BERGAMASCO, R.; GASPAROTTO, F.; REZENDE, L. C. S. H.; YAMAGUCHI, N. U. Pilot Batch-Scale Reactor for Glyphosate Removal Using Hybrid Magnetic Graphene. Chemical Engineering Transactions, v. 60, n., p. 6, 2017.

TARONE, R. E. On the International Agency for Research on Cancer classification of glyphosate as a probable human carcinogen. European Journal of Cancer Prevention, v. 27, n. 1, p. 82-87, 2018. 
UNESCO. The United Nations World Water Development Report 2014: Water and Energy. Paris: 2014

UNITED NATIONS. Transforming our world: the 2030 Agenda for Sustainable Development. 2015. Disponível em http://www.un.org/ga/search/view_doc.asp?symbol=A/RES/70/1\&Lang=E. Acesso em 08/03/2018.

WANG, H.; YUAN, X.; WU, Y.; CHEN, X.; LENG, L.; WANG, H.; LI, H.; ZENG, G. Facile synthesis of polypyrrole decorated reduced graphene oxide-Fe3O4 magnetic composites and its application for the $\mathrm{Cr}(\mathrm{VI})$ removal. Chemical Engineering Journal, v. 262, n. Supplement C, p. 597-606, 2015.

WEIDENHAMER, J. D.; CALLAWAY, R. M. Direct and indirect effects of invasive plants on soil chemistry and ecosystem function. J Chem Ecol, v. 36, n. 1, p. 59-69, 2010.

YAMAGUCHI, N. U.; BERGAMASCO, R.; HAMOUDI, S. Magnetic MnFe2O4-graphene hybrid composite for efficient removal of glyphosate from water. Chemical Engineering Journal, v. 295, n. Supplement C, p. 391-402, 2016.

YAO, Y.; CAI, Y.; LU, F.; WEI, F.; WANG, X.; WANG, S. Magnetic recoverable MnFe2O4 and $\mathrm{MnFe2O4-graphene} \mathrm{hybrid} \mathrm{as} \mathrm{heterogeneous} \mathrm{catalysts} \mathrm{of} \mathrm{peroxymonosulfate}$ activation for efficient degradation of aqueous organic pollutants. Journal of Hazardous Materials, v. 270, n. Supplement C, p. 61-70, 2014. 